ACTA AGROBOTANICA

Vol. 61 (2): 3-10

2008

\title{
INFLUENCE OF PLASMOGENES ON THE PRODUCTIVITY OF MORPHOGENESIS IN STRAWBERRY (FRAGARIA X ANANASSA DUCH.)
}

\author{
Jadwiga Żebrowska', Agata Pacek $^{2}$
}

\begin{abstract}
${ }^{1}$ Department of Genetics and Horticultural Plant Breeding, University of Life Sciences, Akademicka 15, 20-950 Lublin, Poland ${ }^{2}$ Department of Botany, University of Life Sciences, Akademicka 15, 20-950 Lublin, Poland

e-mail: agatapacek@wp.pl
\end{abstract}

Received: 15.09 .2008

\section{S u m m a r y}

Plasmogenes are largely located in mitochondria or plastids and they can influence the inheritance of many plant characteristics. This phenomenon is called cytoplasmic inheritance and can be detected on the basis of the expression of a trait in progeny $F_{1}$ obtained from single and reciprocal crosses.

The aim of this study was to examine the cytoplasmic inheritance of in vitro productivity of morphogenesis in three genotypes of Fragaria x ananassa Duch., i.e. the cultivars 'Dukat', 'Teresa' and the breeding clone no. 590.

Single and reciprocal crosses were done according to Griffing's method 3. The value of general combining ability (GCA) indicated cv. 'Teresa' as the best maternal component for crossing and 'Dukat' as the worst. The negative reciprocal cross effects $\left(r_{i j}\right)$ revealed the cytoplasmic inheritance for cv. 'Dukat' as maternal form and positive $r_{i j}$ for the breeding clone no. 590 indicated the nuclear inheritance of morphogenetic ability. Cv. 'Teresa', as maternal component, showed nuclear inheritance of that trait in crossing with cv. 'Dukat' and with 590 cytoplasmic inheritance. The productivity of morphogenesis in strawberry depended on the parental combination and the direction of crossing.

Key words: chloroplast DNA, Fragaria $x$ ananassa Duch., general combining ability, Griffing's method 3, inheritance, mitochondrial DNA

\section{INTRODUCTION}

Most traits inherited by organisms are associated with genes located on chromosomes in cell nucleus. But sometimes the cytoplasm can influence the inheritance of some traits. That kind of heredity is called cytoplasmic inheritance (extrachromosomal inheritance, extranuclear inheritance) and it is caused by plasmogenes which are largely located in mitochondria or plastids. These two organelle genomes coexist in the cytoplasm of their cells: the mitochon- drial genome, nearly ubiquitous in eukaryotes, and the plastid genome, specific to plants. The mode of inheritance of these two genomes is varied and not always coincident, ranging from strictly maternal to strictly paternal (Harris and Ingram, 1991; Reboud and Zeyl, 1994; Mogensen, 1996; $\mathrm{R}$ ö $\mathrm{h} \mathrm{r}$ et al. 1998). In plants, three modes of inheritance of plastids and mitochondria are known: uniparental maternal, uniparental paternal or biparental organelle inheritance. The numerical proportion of these three modes of inheritance is very different in various taxa of angiosperms (H a g e mann, 1992; 2004). The two cytoplasmic plant genomes, chloroplast DNA (cpDNA) and mitochondrial DNA (mtDNA) are generally inherited in a uniparental way. Most of the angiosperm plants studied exhibit maternal inheritance of cpDNA, but about one-third of the genera investigated display biparental chloroplast inheritance to some degree (Corriveau and Coleman, 1988; Harris and Ingram, 1991; Hagem ann, 1992, 2004; Mogensen, 1996; Zhang et al. 2003). Experimental crosses between parental plants with different chloroplast haplotypes are used to investigate the mode of chloroplast inheritance ( $\mathrm{C}$ a fass o et al. 2001; Mogensen, 1996). Much less is known about the inheritance of plant mtDNA (Sodmergen et al. 2002; Mohanty et al. 2003; Korpelainen, 2004). The contrasted patterns of organelle inheritance and nuclear genes can be used to unravel the complexity of gene flow in plants, as they are predicted to result in very different distribution of genetic diversity within and among populations (B irky et al. 1989; Petit et al. 1993; 2005).

The cytoplasmic inheritance in plants can be detected on the basis of the expression of morphogenetic ability in progeny $F_{1}$ obtained from single and reciprocal crosses. The capacity of cultured plant tissues to undergo morphogenesis, resulting in the 
formation of whole plants, provided opportunities for numerous applications of in vitro plant biology in studies of basic botany, biochemistry, propagation, breeding, and development of transgenic crops (Phillips, 2004).

The aim of this experiment was to determine the influence of genes located in the cytoplasm on productivity of morphogenesis in Fragaria $x$ ananassa Duch. species.

\section{MATERIALS AND METHODS}

\section{Plant material}

The cultivated strawberry Fragaria $x$ ananassa Duch. $(2 \mathrm{n}=8 \mathrm{x}=56)$ belongs to the Rosaceae family. It was described and named in 1766 by the French botanist Duchesne. The species originated from chance hybridizations that occurred in some European botanical gardens between two octopliod species Fragaria virginiana and Fragaria chiloensis, imported from the New World at the end of the $16^{\text {th }}$ century and the middle of $18^{\text {th }}$ century, respectively. The genomic constitution of the parental species remains unknown (L e r c e ta u-Köhler et. al. 2003).

The experiment was conducted in two stages: in the field and in a plant tissue culture laboratory. The objects of the research were two cultivars of Fragaria $x$ ananassa Duch. species: 'Teresa', 'Dukat' and the breeding clone no. 590. The origin of these cultivars and clone is given in Tab. 1.

Obtaining the hybrid material of progeny $F_{1}$ from diallelic crosses according to Griffing's method 3

The hybrid material of progeny $F_{1}$ was obtained via Griffing's method 3. It relies on single and reciprocal crosses without progeny from self-pollination. The positive value of reciprocal cross effects $\left(\mathrm{r}_{\mathrm{ij}}\right)$ shows chromosomal inheritance and the negative value - cytoplasmic inheritance of morphogenetic ability
(Griffing, 1956). The diagram of these crosses is given in Tab. 2. In order to do those crosses, 60 flower buds on each maternal form were emasculated - 30 for each paternal form. The emasculated maternal flowers were pollinated by two paternal forms -30 maternal flowers for each paternal form. Pollen was derived from newly opened flowers and it was kept for about seven days in a desiccator at $0+4^{\circ} \mathrm{C}$. The pollinated maternal flowers were isolated properly and protected from environmental factors. The hybrid material of six progeny combinations $F_{1}$ was obtained from nearly ripe fruits.

\section{Estimation of in vitro morphogenetic ability of $F_{1}$ generation}

The morphogenetic ability of each progeny $F_{1}$ was estimated on the basis of the mean number of microplants, obtained from explants of progeny $F_{1}$ in two subsequent subcultures.

After the superficial sterilization in sodium hypochlorite, the seeds of the progeny combination $F_{1}$ were placed on MS medium (Murashige and Skoog, 1962) without growth regulators and with a limited concentration of sucrose and $\mathrm{pH}=5.7$ (Tab. 3). The achenes were sterilised for $2 \mathrm{~h}$, after that three to five times rinsed in sterile distilled water under aseptic conditions.

Petri plates with seeds were located at temp. $0+4^{\circ} \mathrm{C}$ for eight weeks in order to undergo stratification. After stratification, the plates were kept in a phytotron under controlled light conditions (16h day/ $8 \mathrm{~h}$ night) and temp. $18-20^{\circ} \mathrm{C}$. The germination of the seeds was observed. The seedlings at the cotyledon stage or at the 1-2 leaf stage were placed on sterile MS medium with growth regulators in order to induce in vitro morphogenesis (the medium composition is given in Tab. 3).

Each progeny combination was represented by 40 seedling explants. Each seedling explant was numbered to control further proliferation in two subcultures. The mean number of microplants per explant was estimated for each of six progeny combinations.

Table 1

The origin of the analyzed breeding clone and strawberry cultivars.

\begin{tabular}{cl}
\hline Breeding clone number $/$ cultivar & \multicolumn{1}{c}{ Origin of breeding clone $/$ cultivar } \\
\hline $590 \bullet$ & Paula x $3040=$ Paula x (Senga Sengana x Talisman) \\
'Dukat' & Koralowa $100 \times$ Gorella \\
'Teresa' & Redgauntlet $\mathrm{S}_{1} \times$ Senga Sengana $\mathrm{S}_{1}$ \\
\hline
\end{tabular}


Table 2

Diagram of diallelic cross configuration by Griffing's method 3 (single crossing ${ }^{\mathrm{x}}$ and reciprocal crossing ${ }^{\mathrm{xx}}$ without progeny from self-pollination).

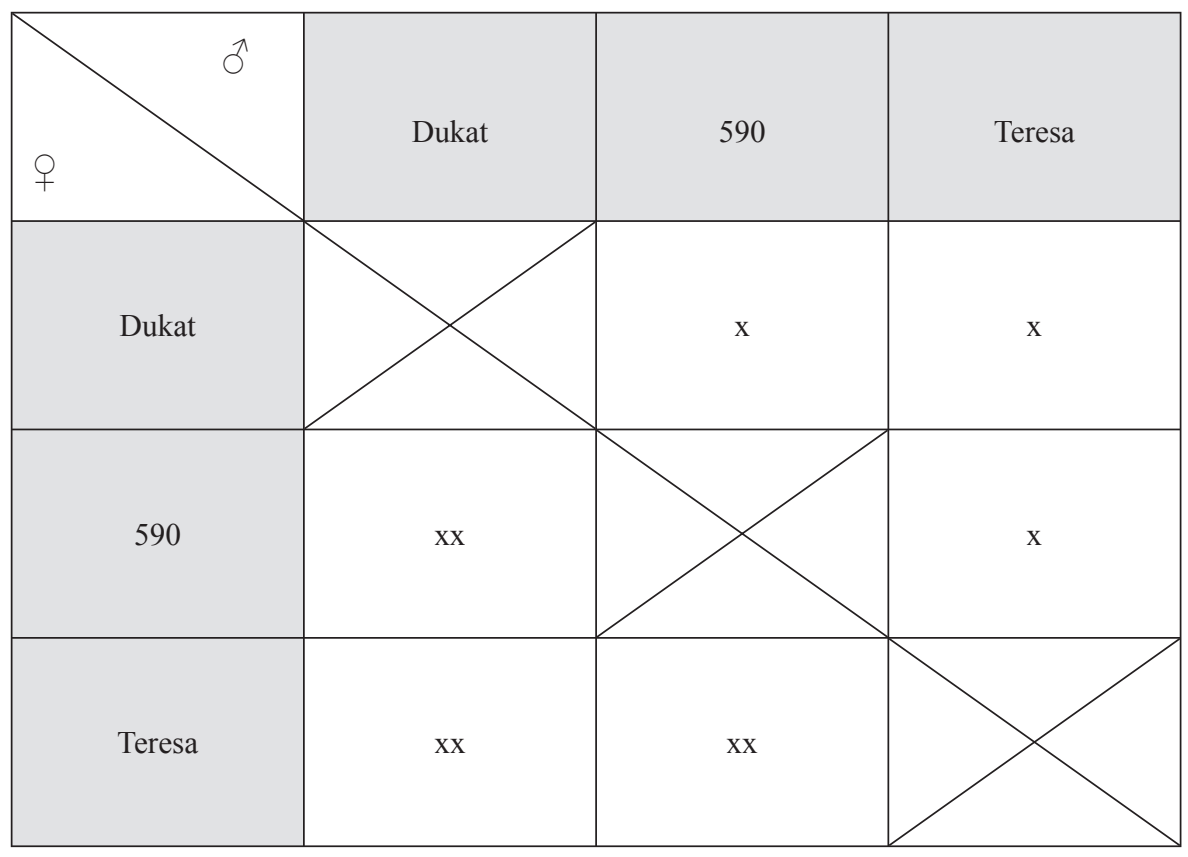

After eight weeks, the number of microplants derived from each seedling explant was counted. One microplant derived from each seedling explant was chosen randomly (40 from each parental combination) and placed again on sterile MS medium with growth regulators. After eight subsequent weeks, the number of microplants produced by individual explants was estimated again. In the experiment, 480 explants were proliferated.

\section{Statistical analysis of obtained results}

The results of the study were statistically evaluated by means of parameters used in estimating the inheritance of quantitative traits. The usefulness of parental forms for transmitting the morphogenetic ability to the progenies was estimated on the basis of general combining ability (GCA). The calculated effects of reciprocal crosses $\left(r_{i j}\right)$ for single crosses $i x j(i<j)$ were used to indicate those maternal forms which transmitted the morphogenetic ability extrachromosomally by plasmogenes (Ubysz-Bor uc ka et al. 1985; Hakizi mana et. al. 2004; M a sny et al. 2005).

\section{RESULTS AND DISCUSSION}

Mean microplant number per explant between two subsequent subcultures varied in the analyzed progeny $F_{1}$. There was observed an increase in the number of microplants during the second explant proliferation (Tab. 4). In general, the total mean number of microplants per explant reached the value of 8.0 in the first proliferation. In the second proliferation, a significantly higher number of microplants per explant was observed (13.0). In the progeny $F_{1}$ of the parental combination 'Dukat' x 590, the number of microplants per explant was the lowest (5.0) in the analyzed plant material after the first subculture. The highest number of microplants was produced by the explants of combination $590 \mathrm{x}$ 'Teresa', both in the first and second proliferation (Tab. 4). Only in the $F_{1}$ progeny combination of the parents 'Dukat' $x$ 'Teresa', the number of microplants produced per explant during the second subculture was almost two times lower (6.0 microplants) compared to the first one, where 11.0 microplants per explant were observed (Tab. 4).

The average values of the number of microplants after two subsequent subcultures for six proge- 
Table 3

Composition of standard MS medium for stratification of strawberry sowing material and strawberry micropropagation.

\begin{tabular}{|c|c|c|}
\hline \multirow{2}{*}{ Components } & \multicolumn{2}{|c|}{ MS medium } \\
\hline & $\begin{array}{l}\text { for stratification } \\
\qquad\left(\mathrm{mg} \times \mathrm{dm}^{-3}\right)\end{array}$ & $\begin{array}{l}\text { for micropropagation } \\
\qquad\left(\mathrm{mg} \times \mathrm{dm}^{-3}\right)\end{array}$ \\
\hline $\mathrm{KNO}_{3}$ & 1900.00 & 1900.00 \\
\hline $\mathrm{KH}_{2} \mathrm{PO}_{3}$ & 170.000 & 170.000 \\
\hline $\mathrm{NH}_{4} \mathrm{NO}_{3}$ & 1650.000 & 1650.000 \\
\hline $\mathrm{MgSO}_{4} \cdot 7 \mathrm{H}_{2} \mathrm{O}$ & 370.000 & 370.000 \\
\hline $\mathrm{CaCl}_{2}$ & 332.000 & 332.000 \\
\hline $\mathrm{H}_{3} \mathrm{BO}_{3}$ & 6.200 & 6.200 \\
\hline $\mathrm{MnSO}_{4} \cdot \mathrm{H}_{2} \mathrm{O}$ & 16.900 & 16.900 \\
\hline FeNaEDTA & 40.300 & 40.300 \\
\hline $\mathrm{CoCl}_{2} \cdot 6 \mathrm{H}_{2} \mathrm{O}$ & 0.025 & 0.025 \\
\hline $\mathrm{ZnSO}_{4} \cdot 7 \mathrm{H}_{2} \mathrm{O}$ & 8.600 & 8.600 \\
\hline KJ & 0.830 & 0.830 \\
\hline myo-inositol & 100.000 & 100.000 \\
\hline nicotinic acid (vit. PP) & - & 0.500 \\
\hline pirydoxine- $\mathrm{HCl}$ (wit. $\mathrm{B}_{6}$ ) & - & 0.500 \\
\hline thiamine- $\mathrm{HCl}$ (wit. $\mathrm{B}_{1}$ ) & - & 0.400 \\
\hline gibberellic acid $\left(\mathrm{GA}_{3}\right)$ & - & 0.010 \\
\hline indolilo-alpha-acetic acid (IAA) & - & 1.000 \\
\hline benzo-alpha-pyrene (BAP) & - & 1.000 \\
\hline agar & 6000.000 & 6000.000 \\
\hline sucrose & 5000.000 & 20000.000 \\
\hline
\end{tabular}


Table 4

Mean number of microplants per explant in the first and second proliferation of the analyzed progeny $\mathrm{F}_{1}$.

\begin{tabular}{l|c|c}
\hline \multirow{2}{*}{ Parental combination } & \multicolumn{2}{|c}{ Progeny $\mathrm{F}_{1}$ explant proliferation } \\
\cline { 2 - 3 } & First proliferation & Second proliferation \\
\hline 'Dukat' x 590 & $5.0 \mathrm{a}$ - & $9.0 \mathrm{~cd}$ \\
$590 \mathrm{x}$ 'Dukat' & $8.0 \mathrm{bc}$ & $14.0 \mathrm{e}$ \\
'Dukat' x 'Teresa' & $11.0 \mathrm{~d}$ & $6.0 \mathrm{ab}$ \\
'Teresa' x 'Dukat' & $7.0 \mathrm{ab}$ & $14.0 \mathrm{e}$ \\
$590 \mathrm{x}$ 'Teresa' & $11.0 \mathrm{~d}$ & $23.0 \mathrm{f}$ \\
'Teresa' x 590 & $9.0 \mathrm{~cd}$ & $13.0 \mathrm{e}$ \\
\hline Total mean & $8.0 \mathrm{a}$ & $13.0 \mathrm{~b}$ \\
\hline
\end{tabular}

- Means followed by the same letter are not significantly different at $\mathrm{P}=0.05$

Table 5

Average values $(\overline{\mathrm{y}})$ of the analyzed trait after two subsequent subcultures for six progenies $\mathrm{F}_{1}$ and maternal $\left(\overline{\mathrm{y}}_{\odot}\right) /$ paternal groups $\left(\overline{\mathrm{y}}_{\bullet} \bullet_{\delta}\right)$.

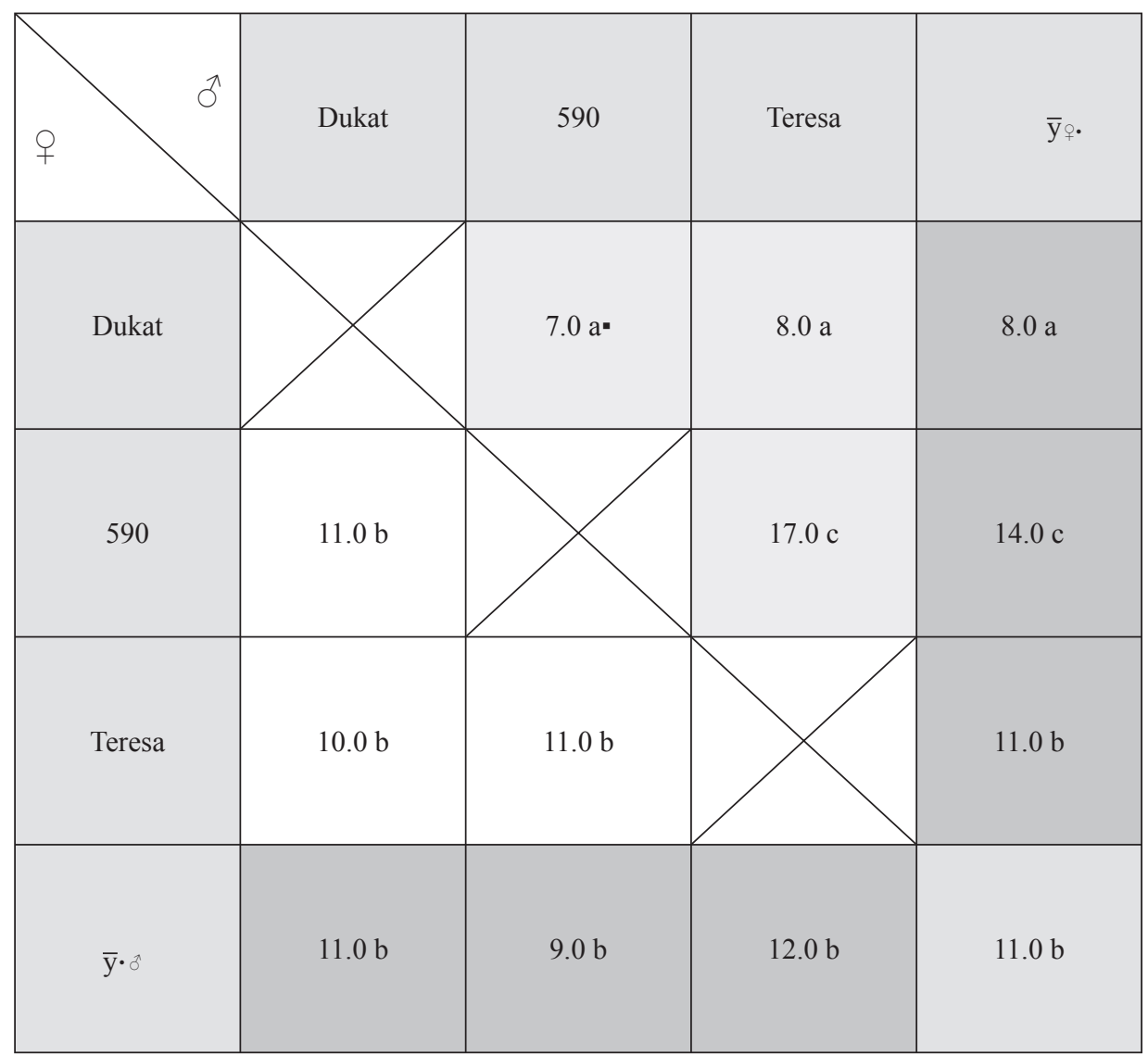

- Means followed by the same letter are not significantly different at $\mathrm{P}=0.05$ 
Table 6

Variability of the analyzed trait of six progenies $\mathrm{F}_{1}$.

\begin{tabular}{|c|c|c|c|c|}
\hline No. & Parental combination & $\begin{array}{c}\text { Variance } \\
\mathrm{S}^{2}\end{array}$ & $\begin{array}{c}\text { Standard } \\
\text { deviation } \\
\mathrm{S}_{\mathrm{d}}\end{array}$ & $\begin{array}{c}\text { Coefficient of } \\
\text { variability }(\%) \\
\text { V }\end{array}$ \\
\hline 1 & 'Dukat' x 590 & 19.437 & 4.409 & 63.267 \\
\hline 2 & 'Dukat' x 'Teresa' & 19.869 & 4.457 & 55.550 \\
\hline 3 & 590 x 'Dukat' & 46.765 & 6.838 & 63.134 \\
\hline 4 & 590 x 'Teresa' & 59.787 & 7.732 & 46.838 \\
\hline 5 & 'Teresa' x 'Dukat' & 40.598 & 6.372 & 62.026 \\
\hline 6 & 'Teresa' x 590 & 25.374 & 5.037 & 44.958 \\
\hline
\end{tabular}

Table 7

General combining ability (GCA) of parental forms and effects of reciprocal crosses $\left(r_{i j}\right)$.

\begin{tabular}{|c|c|c|c|}
\hline No. & Parental combinations & $\mathrm{r}_{\mathrm{ij}}$ & $\mathrm{GCA}_{\odot}$. \\
\hline 1 & 'Dukat'x $590^{\star}$ & \multirow{2}{*}{-1.944} & \multirow{4}{*}{-3.242} \\
\hline 2 & 590 x 'Dukat' •" & & \\
\hline 3 & 'Dukat' x 'Teresa' & \multirow[b]{2}{*}{-1.131} & \\
\hline 4 & 'Teresa' x 'Dukat' & & \\
\hline 5 & 590 x 'Dukat' & \multirow[b]{2}{*}{1.944} & \multirow{4}{*}{1.496} \\
\hline 6 & 'Dukat' x 590 & & \\
\hline 7 & 590 x 'Teresa' & \multirow[b]{2}{*}{2.668} & \\
\hline 8 & 'Teresa' x 590 & & \\
\hline 9 & 'Teresa' x 'Dukat' & \multirow{3}{*}{1.131} & \multirow{5}{*}{1.746} \\
\hline \multirow[t]{2}{*}{10} & 'Dukat' x 'Teresa' & & \\
\hline & & & \\
\hline 11 & 'Teresa'x 590 & \multirow{2}{*}{-2.668} & \\
\hline 12 & 590 x 'Teresa' & & \\
\hline
\end{tabular}

- single cross

* reciprocal cross 
nies $\mathrm{F}_{1}$ and maternal/paternal groups were also significantly varied (Tab. 5). The highest differences in mean number of microplants were observed in case of the analyzed progeny $\mathrm{F}_{1}$, obtained after crossing the breeding clone no. 590 as a maternal form and 'Dukat' or 'Teresa' as paternal forms (11.0 and 17.0 microplants, respectively). In the reciprocal crosses between those two cultivars as maternal forms and the breeding clone no. 590 as a paternal form, the number of produced microplants per explant was 7.0 and 11.0, respectively. The lowest insignificant differences in mean number of microplants were observed in the case of the explants obtained after the crossing of cv. 'Dukat' and 'Teresa' as maternal forms with two paternal genotypes (Tab. 5). On the other hand, the average values of the analyzed trait observed in the reciprocal crosses for cv. 'Dukat' used as a maternal form in single crosses with the breeding clone no. 590 and cv. 'Teresa' were significantly higher (11.0 and 10.0, respectively). Furthermore, in the case of cv. 'Teresa' used as a maternal form in a single cross with the breeding clone no. 590 in the progeny $F_{1}$, the same tendency was observed. The mean number of microplants estimated for the explants obtained in the progeny $\mathrm{F}_{1}$ of the reciprocal crosses 'Teresa' $\mathrm{x}$ 'Dukat' was significantly lower (10.0 and 8.0, respectively).

The variability of the number of microplants obtained from the explants of the parental combinations $590 \mathrm{x}$ 'Teresa' and 'Teresa' $\mathrm{x} 590$, estimated by the coefficient of variability, reached the value below $50 \%$ (Tab. 6). The highest coefficient of variability (over $60 \%$ ) was estimated for 590 x 'Dukat' and 'Teresa' $\mathrm{x}$ 'Dukat' parental combinations (Tab. 6). That indicates that the parental combination and the direction of crossing must be taken into account. However, certain crosses may be better for one trait, but not necessarily as good for other traits ( $\mathrm{L} \mathrm{in}$ and $\mathrm{G} \mathrm{e} \mathrm{ng}, 2008$ ).

The positive effect of GCA was obtained in case of the breeding clone no. 590 (1.496) and a high positive effect in case of cv. 'Teresa' (1.746), whereas in cv. 'Dukat' negative (-3.242). If a particular cultivar has a high GCA effect for a trait with a desirable high level, it means that the cultivar would be a valuable parental form in a breeding program designed to improve that trait (M s n y et al. 2005) and the use of these parental forms should significantly increase the value of the progeny ( $\dot{Z}$ u raw i c z, 1990). But Lin and Geng (2008) suggest that some parental lines with greater combining abilities in one trait may not be so good in another trait.

According to $\mathrm{Ubysz}-\mathrm{B}$ orucka et al. (1985), the negative effect of reciprocal crosses was used to indicate cytoplasmic inheritance. In case of cv. 'Teresa' crossed with cv. 'Dukat', the effect of reciprocal crosses was positive (Tab. 7). On the other hand, the same maternal form crossed with the breeding clone no. 590 revealed a negative value of $r_{i j}$. The obtained results showed the negative effect of $r_{i j}$ for cv. 'Dukat' used as a maternal form, both in the case of crossing with the breeding clone no. 590 and cv. 'Teresa' as paternal forms. The opposite situation was observed for 590 as a maternal form crossed with 'Dukat' and 'Teresa' as paternal forms, where the effects of reciprocal crosses showed a positive value (Tab. 7).

\section{CONCLUSIONS}

1) The influence of plasmogenes on in vitro productivity of morphogenesis should be recognised in Fragaria $x$ ananassa Duch. species.

2) The morphogenetic ability of strawberry explants depended on the parental combination and the direction of crossing.

3) The effects of reciprocal crosses depended mainly on the choice of the maternal component.

4) The best maternal component in the analyzed parental forms was the cultivar 'Teresa' which showed a high and positive value of general combining ability (GCA).

5) The high and negative effect of GCA evaluated for cv. 'Dukat' indicated this maternal form as the worst one.

6) Unstable inheritance of morphogenetic ability was observed in cv. 'Teresa'.

7) The cytoplasmic inheritance of morphogenetic ability was assessed in cv. 'Dukat' through the high and negative effect of reciprocal crosses.

8) In the analyzed explants of the progeny $F_{1}$, there was a tendency to increased productivity of morphogenesis in strawberry during the second subculture.

\section{REFERENCES}

Birky Jr C. W., Fuerst P., Maruyama T. 1989. Organelle gene diversity under migration, mutation, and drift: equilibrium expectations, approach to equilibrium, effects of heteroplasmic cells, and comparison to nuclear genes. Genetics, 121: 613-627.

Cafasso D., Cozzolino S., Caputo P., De Luca P. 2001. Maternal inheritance of plastids in Encephalartos Lehm. (Zamiaceae, Cycadales). Genome, 44: 239-241.

Corriveau J. L., Coleman A. W. 1988. Rapid screening method to detect potential biparental inheritance of plastid DNA and results for over 200 angiosperm species. Am. J. Bot. 75: 1443-1458.

Griffing B. 1956. Concept of general and specific ability in relation to diallel crossing system. Aust. J. Biol. Sci. 9: 463-493.

Hagemann R. 1992. Plastid genetics in higher plants. In R. G. Herrmann (ed.), Plant Gene Research: Cell organelles, 65-96. Springer-Verlag, Vienna. 
Hagemann R. 2004. The sexual inheritance of plant organelles. In H. Daniell H, and C. Chase (eds.), Molecular biology and biotechnology of plant organelles- chloroplasts and mitochondria, 87-108. Springer Publisher, Dordrecht.

Hakizimana F., Ibrahim A. M. H., Langham M. A. C., Haley S. D., Rudd J. C. 2004. Diallel analysis of wheat streak mosaic virus resistance in winter wheat. Crop Sci. 44: 89-92.

Harris S. A., Ingram R. 1991. Chloroplast DNA and biosystematics: the effects of intraspecific diversity and plastid transmission. Taxon, 40: 393-412.

Korpelainen H. 2004. The evolutionary processes of mitochondrial and chloroplast genomes differ from those of nuclear genomes. Naturwissenschaften, 91: 505 -518.

Lercetau-Köhler E., Gučrin G., Laigret F., Denoyes-Rothan B. 2003. Characterization of mixed disomic and polysomic inheritance in the octoploid strawberry (Fragaria $x$ ananassa) using AFLP mapping. Theor. Appl. Genet. 107: 619-628.

Lin D., Geng S. 2008. Multivariate Extension of Griffing's Diallel Analysis. J. Agron. Crop Sci. 157: 52-57.

Masny A., Mądry W., Żurawicz E. 2005. Combining ability analysis of fruit yield and fruit quality in everbearing strawberry cultivars using an incomplete diallel cross design. J. Fruit Ornam. Plant Res. 13: 5-17.

Mogensen H. L. 1996. The hows and whys of cytoplasmic inheritance in seed plants. Am. J. Bot. 83: 383-404.

Mohanty A., Martin J. P., González L. M., Aguinagalde I. 2003: Association between chloroplast DNA and mitochondrial DNA haplotypes in Prunus spinosa L (Rosaceae) populations across Europe. Ann. Bot. 92: 749-755.

Murashige T., Skoog F. 1962. A revised medium for rapid growth and bioassays with tobacco tissue cultures. Plant Physiol. 15: 473-497.

Petit R. J., Duminil J., Fineschi S., Hampe A., Salvini D., Vendramin G. G. 2005. Comparative organization of chloroplast, mitochondrial and nuclear diversity in plant populations. Mol. Ecol. 14: 689-701.

Petit R. J., Kremer A., Wagner D. B. 1993. Finite island model for organelle and nuclear genes in plants. Heredity, 71: 630-641.

Phillips G. C. 2004. In vitro morphogenesis in plants - recent advances. In Vitro Cell. Dev. Biol.-Plant. 4: 342345.

Reboud X., Zeyl C. 1994. Organelle inheritance in plants. Heredity, 72: 132-140.

Röhr H., Kües U., Stahl U. 1998. Organelle DNA of plants and fungi: Inheritance and recombination. Prog. Bot. 60: 39-87.

Sodmergen, Zhang Q., Zhang Y., Sakamoto W., Kuroiwa T. 2002. Reduction in amounts of mitochondrial DNA in the sperm cells as a mechanism for maternal inheritance in Hordeum vulgare. Planta, 216: 235-244.
Ubysz-Borucka L., Mądry W., Muszyński S. 1985. Podstawy statystyczne genetyki cech ilościowych w hodowli roślin. / Statistical genetics of quantitative traits in plant breeding. Wydawnictwo SGGW-AR, Warszawa.

Zhang Q., Liu Y., Sodmergen. 2003. Examination of the cytoplasmic DNA in male reproductive cells to determine the potential for cytoplasmic inheritance in 295 angiosperm species. Plant Cell Physiol. 44: 941-951.

Żurawicz E. 1990. Odziedziczalność najważniejszych cech ilościowych truskawki (Fragaria $x$ ananassa. Duch.). / Heritability of the most important quantitative traits of strawberry (Fragaria x ananassa. Duch.). Wyd. Inst. Sadow. Kwiac., Skierniewice.

\section{Wplyw plazmogenów \\ na produktywność morfogenezy u truskawki (Fragaria $x$ ananassa Duch.)}

\section{Streszczenie}

Plazmogeny zlokalizowane są głównie w mitochondriach oraz plastydach i mogą wpływać na dziedziczenie wielu cech u roślin. Zjawisko to określa się mianem dziedziczenia cytoplazmatycznego, wykrywanego na podstawie ekspresji danej cechy w pokoleniu $\mathrm{F}_{1}$, uzyskanym z krzyżowań prostych i odwrotnych.

Celem badań było określenie wpływu dziedziczenia cytoplazmatycznego na produktywność morfogenezy in vitro trzech genotypów Fragaria $x$ ananasa Duch. tj. odmiany 'Dukat', 'Teresa' i klonu hodowlanego nr 590.

Proste i odwrotne krzyżowania wykonano według trzeciej metody Griffing’a. Najlepszym komponentem matecznym określonym na podstawie ogólnej zdolności kombinacyjnej (GCA) była odmiana 'Teresa', natomiast najsłabszym odmiana 'Dukat'. Negatywny efekt krzyżowań odwrotnych $\left(\mathrm{r}_{\mathrm{ij}}\right)$ wskazał na cytoplazmatyczne dziedziczenie zdolności morfogenetycznych u odmiany 'Dukat' jako formy matecznej, natomiast pozytywny $r_{i j}$ na dziedziczenie jądrowe u klonu hodowlanego nr 590. U odmiany 'Teresa' jako komponentu matecznego, w krzyżowaniu z odmianą 'Dukat', stwierdzono dziedziczenie jądrowe danej cechy a cytoplazmatyczne w krzyżowaniu z klonem hodowlanym nr 590. Produktywność morfogenezy badanych odmian i klonu truskawki zależała od kombinacji rodzicielskiej oraz kierunku krzyżowania. 